\title{
Failure to detect Helicobacter pylori in tap water sources in Al- Najaf and Babylon provinces by using PCR based on ureB gene.
}

\author{
O.M.Hadi R. H. Fadel H. K. Hussein \\ Coll. of Health \& Medical Technology/ Kuffa.
}

\begin{abstract}
(500) sample collected from the study area, divided into (250) from the province of Najaf and (250) from the province of Babylon, and distributed by two models for each sample. I use the first model to estimate the level of free chloride, $\mathrm{pH}$, dissolved substances college and temperature, while the use the other form of the same sample to check for the presence of bacteria in tap water in a PCR study showed a large disparity in the levels of $\mathrm{pH}$, free chlorine, dissolved substances college and the temperature you two provinces were the highest percentages for the Abbasia in Najaf Ashraf and the least in the Alhaidariya in the same province study also demonstrated the existence of significant correlation between the level of free chloride each of the temperature, dissolved substances College and the $\mathrm{pH}$ while the highest in the region of Mahaweel in the province of Babylon, and the least in Jordan in the same area of the province and which should be mentioned to him the failure mode (PCR) in detecting the presence of Helicobacter pylori bacteria in tap water in the both provinces .

H.pylori :- Helicobacter pylori .

T D S :- Total dissolved solids .

PCR :- Polymerase chain reaction .
\end{abstract}

\section{Introduction}

Feces-contaminated water may be a source of infection; an association between $H$. pylori and the absence of hot running water was found in some studies. An increased risk of infection was observed in children who swam in rivers, streams, or swimming pools in the southern Colombian Andes. The organism has not been isolated from water [1] except in two instances in which it was detected using the polymerase chain reaction on samples from Aldana, Colombia and Lima, Peru [2]. In Sweden, exposure to sewage among sewage workers did not cause an increased risk of infection [3]. Children who obtained their drinking water from local streams in the Columbian Andes were also found to have an increased prevalence of $H$. pylori[4].A case-control study of 407 children aged 2 months to 12 years in Peru also concluded that water was the vehicle of infection: children who used the municipal water supply had a higher prevalence of $H$. pylori infection than children who used private wells [5]. These results were confirmed by another study that identified $H$. pylori in drinking water in Peru [2]. Although these studies suggest that transmission may occur via water and food in developing countries, comparable results have not been observed in industrialized countries [6].Although the route of transmission of Helicobacter pylori remains unknown, drinking water has been considered a possible transmission vector. It has been shown previously that biofilms are a protective niche for several pathogens, protecting them from stressful conditions, such as low carbon concentration, shear stress, and less-thanoptimal temperatures [7].Clean water is essential to life. It is still a challenge towards the control of microbial infections. Intervention techniques employed to treat water include physical removal of pathogens, chemical treatment and heat and ultraviolet (UV) radiation. Bacteriological 
water quality mainly rely on type of disinfectants used and ability to sustain enough residual concentrations, the concentration of biodegradable compounds in water as well as prevailing water temperature and the piping material used $[8,9]$.Several studies have highlighted the presence of the organism or its DNA in water [9]. Since fecal contaminated water has the potential for fecal-oral transmission of the organism [10]. Most people might be at risk of becoming infected with the organism due to the primitive water sources that are still the main water sources in some communities [7].Some studies demonstrated that water-borne transmission of $H$. pylori could be an important source of infection in developing countries especially if the water supply is untreated [11].Helicobacter pylori has the ability to remain cultivable in natural waters at a low temperature [12]. Under unfavorable conditions $H$. pylori turns to a non-cultivable form [13].There is still a need to demonstrate the conversion to a bacillary form so as to prove the involvement of the coccoid form in the transmission and waning nature of the infection. However, an earlier study had demonstrated that the coccoid forms do not lose completely the maintenance factors or properties and might be able to infect mice [14] thereby strengthening the argument of the possibility of transmission by the coccoid form. The greatest obstacle to proving that water is a transmission route is the fact that $H$. pylori has never been cultured from drinking-water distribution systems (DWDS) using standard cultivation techniques [15].Survival of $H$. pylori in different types of waters has been reported to extend from days to weeks at temperatures between 4 and $15 \mathrm{C}^{\circ}$ over a wide $\mathrm{pH}$ range [16]. Biofilms in drinking water systems have been reported as possible reservoirs of $H$. pylori [17]. Free living amoebae have been found to promote growth and survival of $H$. pylori under experimental conditions [18].

\section{Materials and Methods}

\section{Samples collection}

One hundred milliliter screw capped containers were used to collect drinking water from the area of the study.

\section{Water samples for PCR}

The first water sample was filtered directly by using the filtration system (negative pressure by vacuuming system) with $0.22 \mu \mathrm{m}$ cellulose nitrate filter paper (Sartorius stedim, Biotech, Germany). The filter paper was cut by using sterile scalpels. Biofilm was washed by using $2 \mathrm{ml}$ TE Buffer in sterile screw caped test tube (pyrex, USA), centrifuged at 5000. The pelts were

used directly to detect $H$. pylori by PCR technique. [19].

Water samples for detection of free chlorine level, pH, total dissolved solids, and temperature

The second sample was used to measure $\mathrm{pH}$, TDS, temperature and free chlorine level. Portable digital (free chlorine level, $\mathrm{pH}$, total dissolved solids, and temperature) meters (figure 2) were used locally.

\section{Statistical Analysis}

Statistical analysis was performed by using SPSS computing program version 16 for the analysis of the results.

\section{Results}

\section{Analysis of water samples for free chlorine level (FCL), pH, total dissolved solids (TDS) and temperature}

Water supply from various areas of AlNajaf and Babylon provinces were analyzed for free chlorine level (FCL), $\mathrm{pH}$, total dissolved solids (TDS) and temperature (Tm) in order to verify the relevance of the role of $H$. pylori transmission with water parameters. As shown in figure $2 \mathrm{FCL}, \mathrm{pH}$, TDS and Tm values were varied in various areas of Al-Najaf province. Thus the lowest 


\section{$\begin{array}{llll}\text { AL-Qadisiya Journal of Vet.Med.Sci. } & \text { Vol./12 } & \text { No./1 }\end{array}$}

values of biochemical parameters were obtained in Al-Haidaria area while the highest one is evidenced in Al-Abbasia area. As shown in table 1 and figure 3 the linear regression analysis revealed significant positive correlation for FCL with the Tm(r: 0.94, p:0.001), TDS (r: 0.78, p:0.01) and $\mathrm{pH}$ (r: 0.8, p:0.01).In Babylon province compatible results were obtained for FCL, $\mathrm{pH}$, TDS and Tm in which the investigated parameters were found to be altered in different areas (figure 4). The lowest values of the biochemical parameters were observed in Al-Hashimia area while the highest magnitudes were demonstrated in Al-Mahaweel area. As shown in table 1 and figure 5 the linear regression analysis illustrated significant positive correlation for the FCL with the Tm (r: 0.84, p:0.001), TDS (r: 0.93, p:0.001) and pH (r: 0.96, p:0.001).
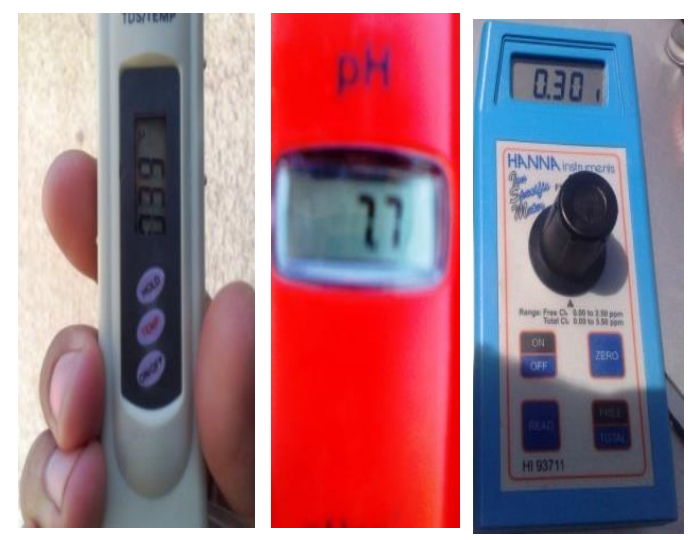

Figure 1 Portable digital meters

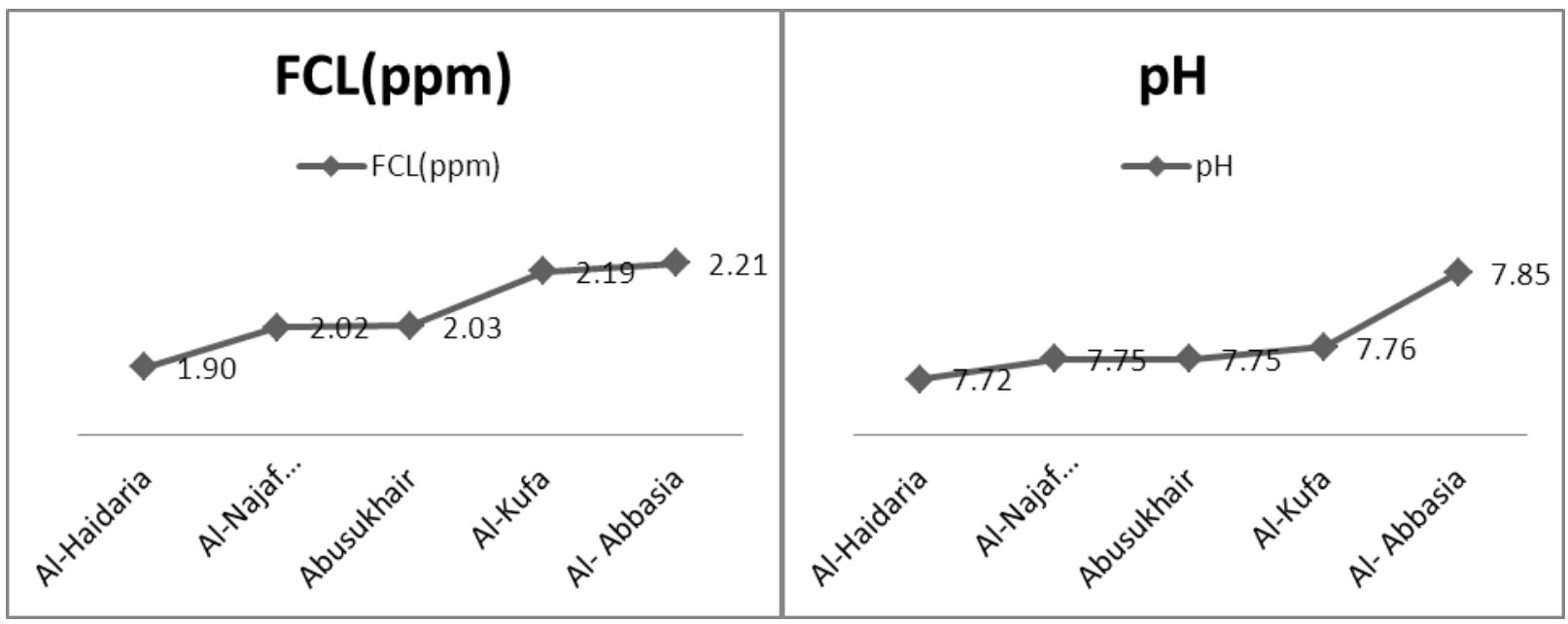


AL-Qadisiya Journal of Vet.Med.Sci. $\quad$ Vol./12 No./1 2013

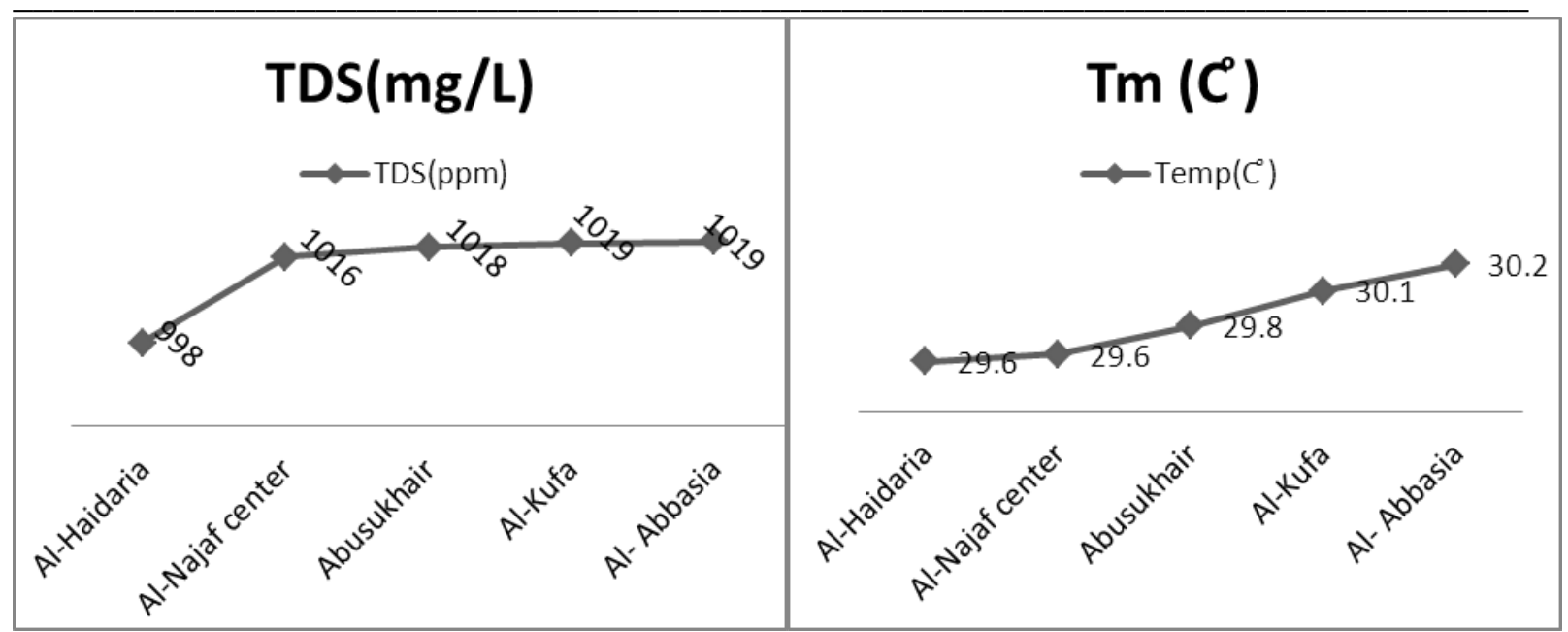

Figure 2: Values of free chlorine level (FCL), $\mathrm{pH}$, total dissolved solids (TDS) and temperature (Tm) in water supply of various areas in Al- Najaf province.
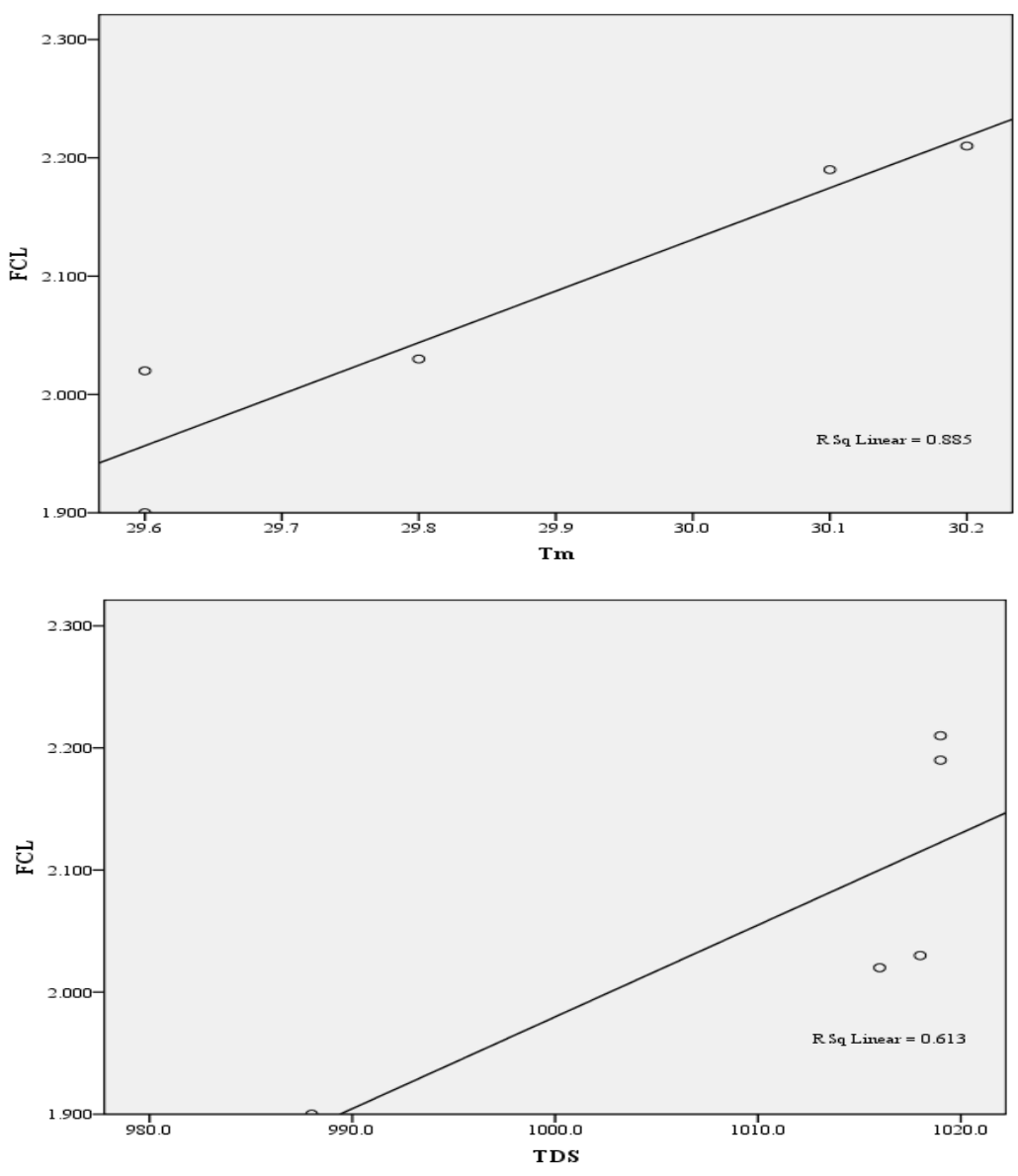
$\begin{array}{llll}\text { AL-Qadisiya Journal of Vet.Med.Sci. } \quad \text { Vol./12 } & \text { No./1 }\end{array}$

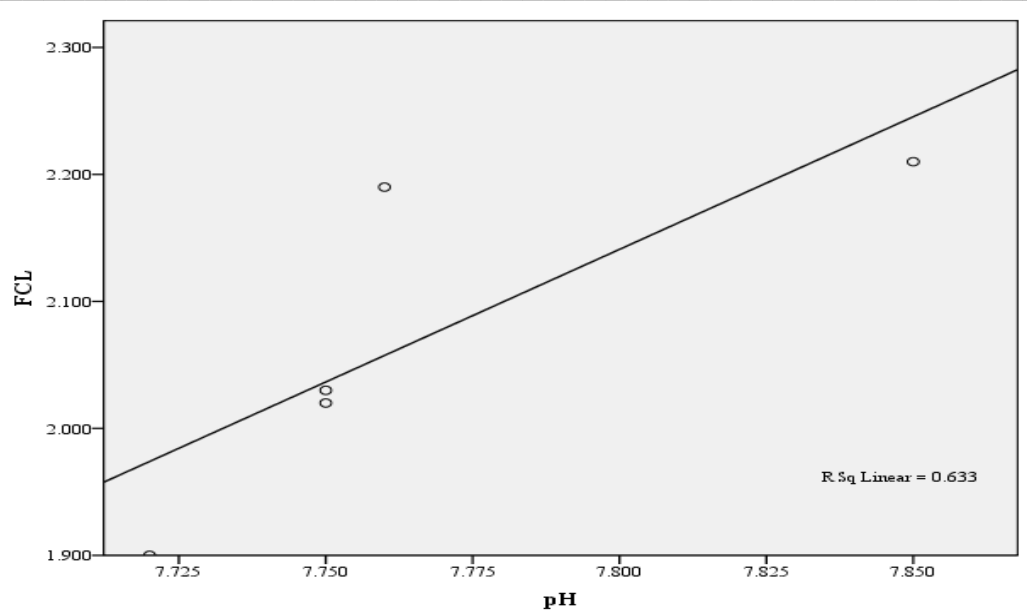

Figure 3: The positive correlation between the free chlorine level and other biochemical parameters (Tm, pH and TDS) in Al- Najaf province.

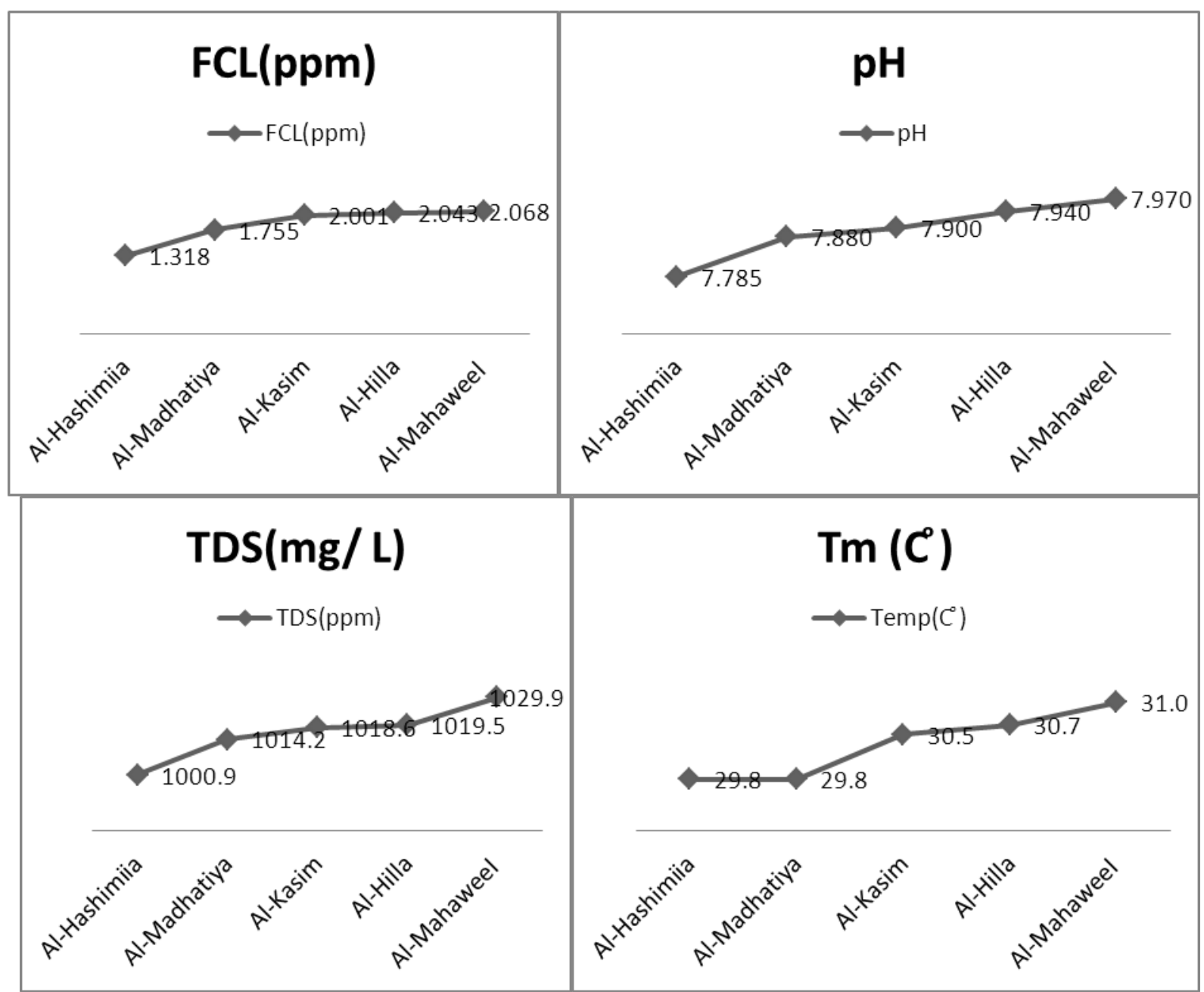

Figure 4: Values of free chlorine level (FCL), $\mathrm{pH}$, total dissolved solids (TDS) and temperature $(\mathrm{Tm})$ in water supply of various areas in Babylon province. 


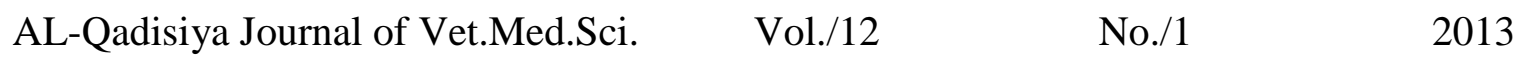
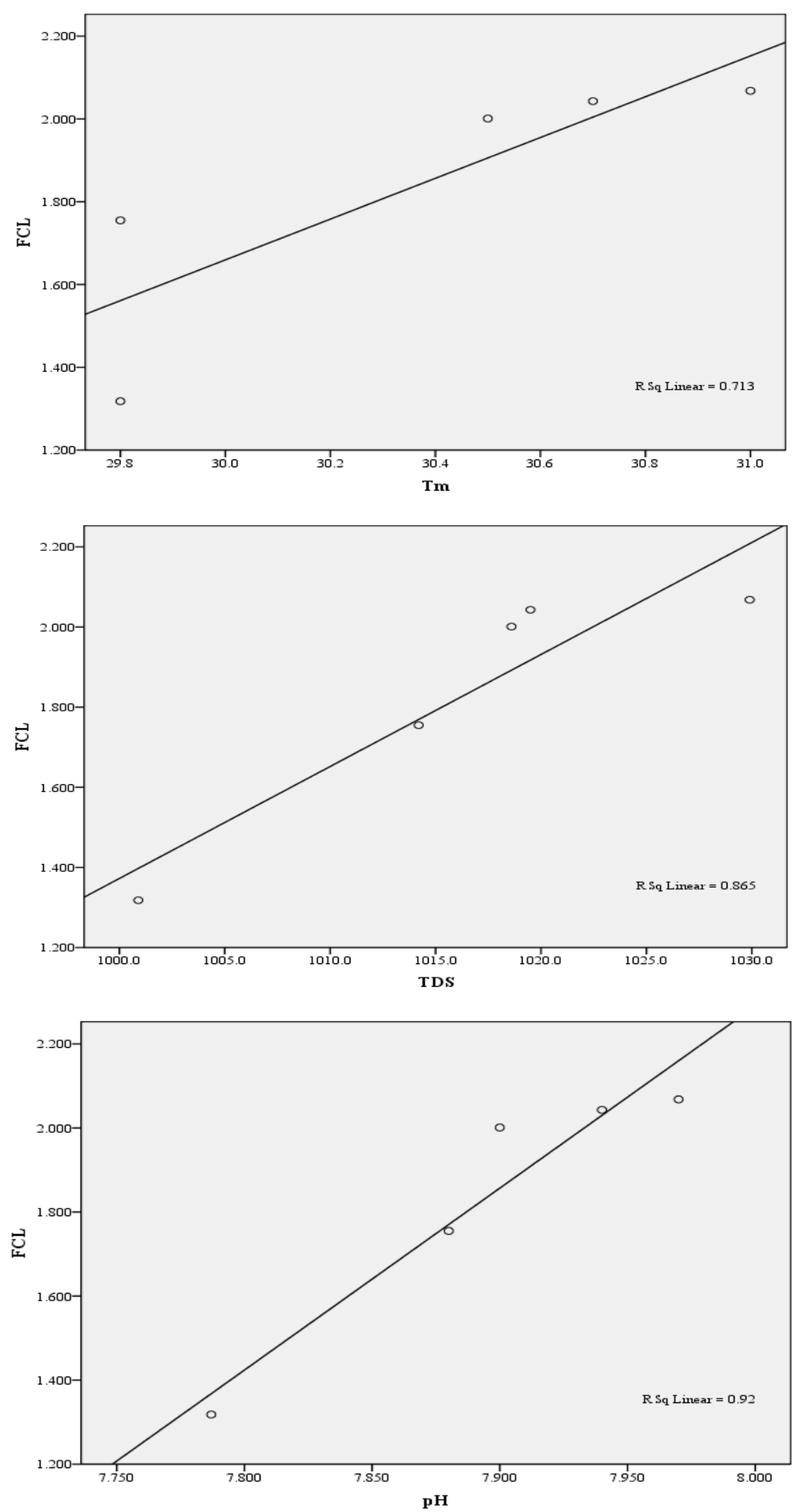

Figure 5: The positive correlation between the free chlorine level and other biochemical parameters (Tm, pH and TDS) in Babylon province. 

AL-Qadisiya Journal of Vet.Med.Sci.
Vol./12
No./1
2013

Table 1: Correlation of free chlorine level with temperature, total dissolved solids and $\mathrm{pH}$ in water supply of different areas in Al- Najaf and Babylon provinces

\begin{tabular}{||l||l|l||l|l||}
\hline & \multicolumn{2}{|c||}{ Al-Najaf province } & \multicolumn{2}{|c||}{ Babylon province } \\
& $\mathrm{r}$ & $\mathrm{p}$ & $\mathrm{p}$ & $\mathrm{p}$ \\
\hline Tm & 0.94 & 0.001 & 0.84 & 0.001 \\
& & & & \\
TDS & 0.78 & 0.01 & 0.93 & 0.001 \\
& & & & \\
$\mathrm{pH}$ & 0.80 & 0.01 & 0.96 & 0.001 \\
\hline
\end{tabular}

\section{Results of polymerase chain reaction analysis}

Water supply from different areas of AlNajaf and Babylon provinces were analyzed by polymerase chain reaction technique for H. pylori ure B gene. Unfortunately positive findings could not be obtained during the current investigation.

\section{Discussion}

Parameters of water supply which are free chlorine level (FCL), it is also called as the break point, $\mathrm{pH}$, total dissolved solids (TDS) and temperature (Tm) were measured to perceive their effects on the transmission of $H$. pylori through the water supply.Chlorine readily combines with chemicals dissolved in water, microorganisms, animal and plant materials, and others. These components use up chlorine and comprise the chlorine demand of the treatment system. It is important to add sufficient chlorine to the water to meet the chlorine demand and provide residual disinfection. The chlorine that does not combined with other components in the water is free (residual) chlorine. It is called the breakpoint. An ideal system supplies free chlorine at a concentration of $0.3-0.5 \mathrm{ppm}$ (Wilkes University Center for environmental quality environmental engineering and earth sciences). Recommended $\mathrm{pH}$ values are 6.58.5 and even may be up to 9.5 [20]. Acceptable TDS levels are 500-1000 $\mathrm{mg} / \mathrm{L}[21]$.In the present investigation the free chlorine level of different areas in AlNajaf and Babylon provinces showed approximately at least three folds elevations higher than the recommended level. The $\mathrm{pH}$ values were found to be within the acceptable ranges. However TDS levels were found to be higher than those of the recommended values in different areas of Al-Najaf and Babylon provinces.The temperature of water supply was observed to be within the ranges that ensure efficient chlorine treatment[22]. However, it is essentially depending on climate and varied from one to one.The significant positive correlations of the chlorine free level with the temperature and $\mathrm{pH}$ values could be attributed that elevation of temperature or $\mathrm{pH}$ may provide suitable environment to supply free chlorine level. On the other hand the significant positive correlation of FCL with TDS is too difficult to be interpreted. Logically, the increase of TDS in the water will consume more chlorine and leave less residual of this element. However, there may be other causes that involved in the significant positive correlation of FCL with TDS. Such causes need to be clarified by further investigation.Water samples were analyzed for $H$. pylori DNA hoping that the detection of this DNA may be a clue for the transmission route of $H$. pylori through the water.Unfortunately, detection of $H$. pylori genome in water supply could not be achieved during the present investigation. This observation is not a crucial limit for the absence of the $H$. pylori genome and/ or viable cells. The interpretation of such 
findings may include three factors. The first one is the very low number of $H$. pylori cells and/ or DNA molecules found in the water supply from which only $100 \mathrm{ml}$ of water is taken for analysis by PCR technique, so that the sample may do not contain the genome of $H$. pylori. The second factor is the technical difficulties of PCR method which may be involved in directing the results. The third one may be related to the presence of PCR inhibitors in the water.When the results of the current study were compared to those reported by others worldwide, some consistence was observed. In the United States [23] had stated that PCR technique was failed to identify $H$. pylori genome in water supply. $H$. pylori-specific ureA gene was not detected in the groundwater of district $\mathrm{C}$ along four rivers in the Tohoku region of Japan [24].[25] have failed to demonstrate $H$. pylori DNA in water supply or reclaimed wastewater in Belgium, Spain, and Italy. In [19] could not identify H. pylori DNA by using highly sensitive real-time PCR assays in any of the samples which were collected from drinking and environmental water.Several studies have suggested that waterborne transmission of $H$. pylori was positively correlated with the consumption of untreated or low quality water supply[26]. Some other reports have demonstrated a detection of $H$. pylori DNA in water supply.[27] have reported that the DNA of $H$. pylori was present in drinking, river, lake, or seawater. [28] have detected H. pylori DNA in the middle and lower parts of one river in Japan. Gia oet al., 2008 have stated that $H$. pylori may present in water but DNA isolation alone does not provide any indication of the viability of the bacterium. Isolation of $H$. pylori from water samples was failed but its DNA was found in $26 \%$ samples.

\section{References}

1. Neale, K. R. and Logan, R. P. H. (1995) The epidemiology and transmission of Helicobacter pylori infection in children. Aliment.Pharmacol.Ther. 9(2): 77-84.

2. Hulten, K., Han, S. W., Enroth, H., Klein, P. D., Opekun, A. R., Gilman, R. H., Evans, D. G., Engstrand, L., Graham, D. Y. and Elzaatari, F. (1996) Helicobacter pylori in the drinking water in Peru. Gastroenterology. 110: 1031-1035

3. Friis, L., Engstrand, L. and Edling, C. (1996)Prevalence of Helicobacter pylori infection among sewage workers.Scandinavian Journal of Work, Environment and Health. 22: 364-368.

4. Goodman, K. J. et al. (1996). Helicobacter pylori infection in the Colombian Andes: a populationbased study of transmission paths. American Journal of Epidemiology. 144: 290-299.
5. Klein, P. D., Graham, D. Y., Gaillour, A., Opekun, A. R. and Smith, E. O. (1991) Water source as risk factor for Helicobacter pylori infection in Peruvian children.Gastrointestinal Physiology Working Group. Lancet, 337: 1503-1506.

6. van Duynhoven, Y.T. and de Jonge, R. (2001) Transmission of Helicobacter pylori : a rolefor food?. Bulletin of the World Health Organization. 79: 455-460.

7. Dube, C., Tanih, N. F., Clarke, A. M., Mkwetshana, N., Green, E. and Ndip, R. N.(2009) Helicobacter pylori infection and transmission in Africa: Household hygiene and water sources are plausible factors exacerbating spread. Afr. J. Biotechnol. 8(22):6028-6035.

8. Riley, R., Beanland, C. and Bos, H. (2002) Establishing the shelf life of flexible colonoscopies. J. Soc. Gastroenterol. Nutr. Assoc. 25(3): 114-119. 


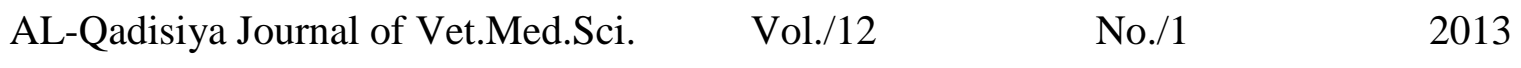

9. Azevedo, N.F., Almeida, C., Cerqueira, L., Dias, S., Keevil, C.W. and Vieira, M.J. (2007) Coccoid form of Helicobacter pylori as a morphological manifestation of cell adaptation to the environment. Appl. Environ. Microbiol. 73(10): 34233427.

10. Liu, Z.F., Chen, C.Y., Tang, W., Zhang, J.Y., Gong, Y.Q., Jia, J.H. (2006). Gene-expression profiles in gastric epithelial cells stimulated with spiral and coccoid Helicobacter pylori. J. Med. Microbiol.55: 10091015.

11. Nala, P.N., Jagals, P. and Joubert, G. (2003)The effect of a waterhygiene educational programme on the microbiological quality of container stored water in households. Water SA, 29:2-7.

12. Gribbon, L.T. and Barer, M. R. (1995)Oxidative metabolism in nonculturable Helicobacter pylori and Vibrio vulnificus cells studied by substrate enhanced tetrazolium reduction and digital image processing. Appl. Environ. Microbiol. 61: 3379-3384.

13. Sörberg, M., Nilsson, M., Hanberger, H. and Nilsson, L.E. (1996) Morphologic conversion of Helicobacter pylori from bacillary to coccoid form. Eur. J. Clin. Microbiol. Infect. Dis. 15: 216-2.

14. She, F., Lin, J., Liu, J., Huang, C. and $\mathrm{Su}, \mathrm{D}$. (2003) Virulence of waterinduced coccoid Helicobacter pylori and its experimental infection in mice.World J. Gastroenterol. 159(3): 516-520.

15. Gia o, M. S., Azevedo, N. F., Wilks, S. A., Vieira, M. J. and Keevil, C. W. (2008) Persistence of Helicobacter pylori in Heterotrophic DrinkingWater Biofilms. Applied and
Environmental Microbiol., 74(19): 5898-5904.

16. Beneduce, L., Tarantino, D., Spano, G., Libergoli, N., Labonia, M. and Massa, S. (2003) Survival of Helicobacter pylori in water.World J. Microbiol.Biotech. 19:505-508.

17. Bunn, J.E.G., MacKay, W.G., Thomas, J.E., Reid, D.C. and Weaver, L.T. (2002)Detection of Helicobacter pylori in drinking water biofilms: implications for transmission in early life. Lett. Appl. Microbiol. 34: 450-454.

18. Winiecka-Krusnell, J., Wreiber, K., Euler, A.V., Engstrand, L. and Linder, E.(2002)Free-living amoebae promote growth and survival of Helicobacter pylori. Scand. J. Infect. Dis. 34:253-256.

19. Janzon, A., Sjo“ling, Å., Lothigius, ̊., Ahmed, D., Qadri,F. and Svennerholm, A. M.(2009)Failure to detect Helicobacter pylori DNA in drinking and environmental water in Dhaka, Bangladesh, using highly sensitive real-time PCR assays. Applied Environ. Microbiol. 75(10): 3039-3044.

20. Obropta, C. C. and Goodrow, S. M. (2006) Interpreting drinking water quality analysis what do the numbers mean? 6th Edition, Rutgers Cooperative Research \& Extension, Cook College-Rutgers University New Brunswick, NJ 08903..

21. California Urban Water Agencies (CUWA) (2008)Drinking Water Treatment Evaluation: Technical Memorandum 1: Definition of Study Boundaries.

22. Ilkes University Center for environmental quality environmental engineering and earth sciences Chlorination of drinking water private well owner guide: Available at URL http:// 
$\begin{array}{llll}\text { AL-Qadisiya Journal of Vet.Med.Sci. } & \text { Vol./12 } & \text { No./1 }\end{array}$

www.water-research.net, accessed at $4 / 5 / 2011$.

23. McDaniels, A., Wymer, E. L., Rankin, C. and Haugland, R. (2005) Evaluation of quantitative real time PCR for the measurement of Helicobacter pylori at low concentrations in drinking water. Water Research 39:4808-4816.

24. Fujimura, S., Kato, S. and Watanabe, A. (2008) Water source as a Helicobacter pylori transmission route: a 3-year follow-up study of Japanese children living in a unique district J. Med. Microbiol. 57:909910.

25. Bo“ckelmann, U., Do“rries, H. H., Ayuso-Gabella, M. N., Salgot de Marcay, M., Tandoi, V., Levantesi, C., Masciopinto, C., Van Houtte, E., Szewzyk, U., Wintgens, T.and Grohmann, E. (2009) Quantitative PCR monitoring of antibiotic resistance genes and bacterial pathogens in three European artificial groundwater recharge systems. Appl. Environ. Microbiol. 75:154-163.

26. Karita, M., Teramukai, S. and Matsumoto, S. (2003)Risk of Helicobacter pylori transmission from drinking well water is higher than that from infected interfamilial members in Japan. Dig. Dis. Sci. 48:1062-106.

27. Baker, K. H., and Hegarty,J. P. (2001) Presence of Helicobacter pylori in drinking water is associated with clinical infection. Scand. J. Infect. Dis.33:744-746.

28. Fujimura, S., Kato, S. and Watanabe, A. (2008) Water source as a Helicobacter pylori transmission route: a 3-year follow-up study of Japanese children living in a unique district J. Med. Microbiol. 57:909910.

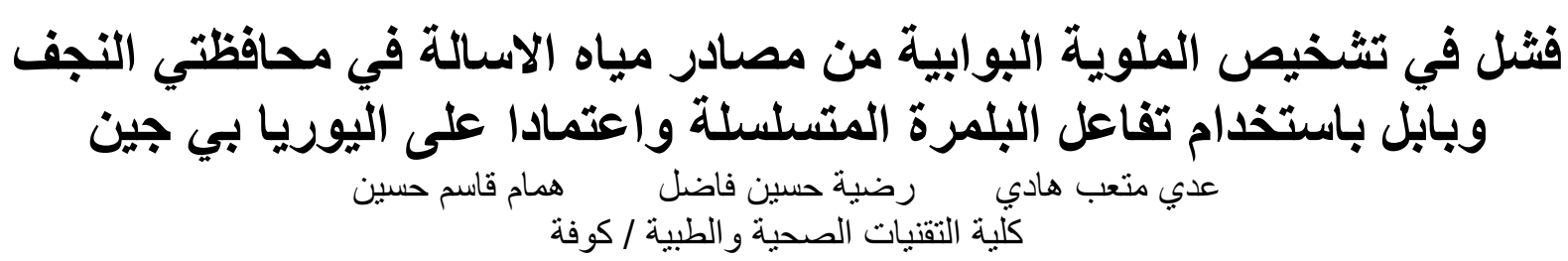

\section{الخلاصة}

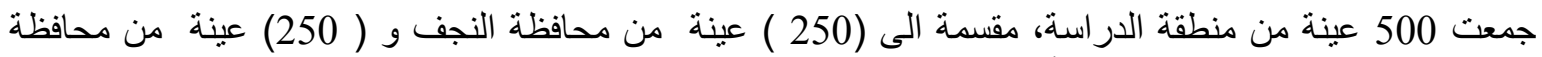

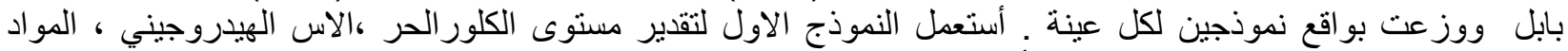

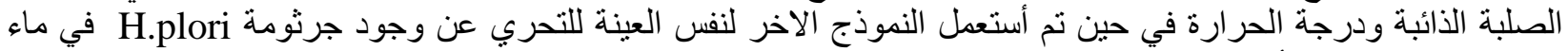

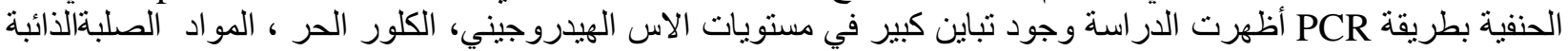

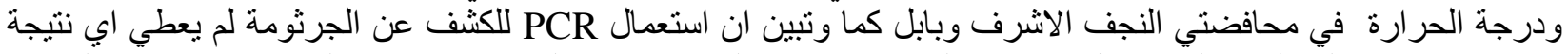

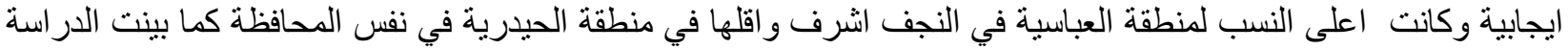

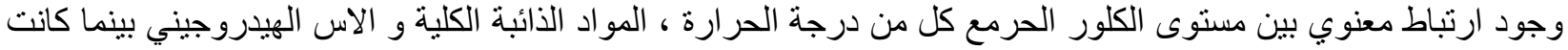

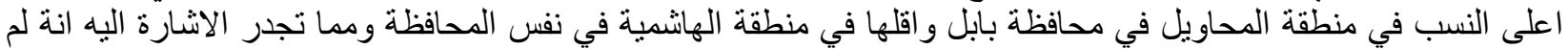

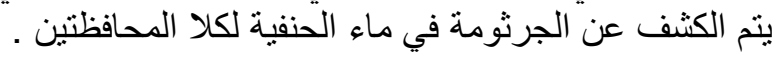

